\title{
Article
}

\section{Dispute Resolution in the Chinese Belt and Road Initiative}

\author{
The Role of Mediation
}

Henneke Brink*

In this article, I will first describe the Belt and Road Initiative (BRI), its legal context and implications. Then I will describe the current dispute resolution 'landscape', the manner in which mediation is perceived in China and how it is promoted and provided in the context of the BRI. Lastly, I will reflect on the significance of the so-called Singapore Convention on Mediation.

\section{About the Belt and Road Initiative}

The Chinese BRI can be roughly described as an international - or almost global - project for the development of infrastructure, trade and international cooperation. In less than a decade, it gained a mindboggling magnitude, purportedly currently engaging some 140 countries - although the limits of its realm are not entirely clear.

The BRI - in Chinese still officially known as 'One Belt One Road' - is the brainchild of Chinese President Xi Jinping, who first talked about the idea in a 2013 speech in Kazakhstan. Recalling a romantic image of ancient trade routes that connected the Orient to Europe and beyond, he proposed renewed cooperation to reconstruct and revive what he referred to as the 'Silk Road

Henneke Brink is a Dutch lawyer, mediator, and owner of Hofstad Mediation. She carries out research and writes about topics concerning the relation between mediation and (inter)national formal justice systems.
Economic Belt'. ${ }^{1}$ This land-based 'Belt' connects China, Central Asia, the Middle East, South Asia, Russia and Europe. One month later, speaking in Indonesia, he proposed the resurrection of a '21st century Maritime Silk Road'. ${ }^{2}$ The maritime 'Road' links China's coasts with Southeast Asia, the Middle East, Africa and Europe via the South China Sea, the Indian Ocean and the South Pacific. The project is aimed for completion in 2049, to coincide with the 100th anniversary of the People's Republic of China.

The BRI encompasses not only 'hard' infrastructure projects - the construction of roads, railways, ports, power plants, mining projects and the installation of fibre-optic cables - but also manifold 'soft' cooperative initiatives on a range of topics and fields. These include financial and debt sustainability, health care, environmental impact and sustainability, seismological research, media, academic research, culture and

1 Xi Jinping's speech at Nazarbayev University, Astana Kazakhstan, 7 September 2013. Retrieved from www.fmprc.gov.cn/mfa_eng/ topics_665678/xjpfwzysiesgjtfhshzzfh_665686/t1076334.shtml. 'The envisaged economic belt along the Silk Road is inhabited by nearly three billion people and it represents the biggest market in the world, with enormous, unparalleled potential for trade and investment cooperation between the countries involved. We should discuss a proper arrangement for trade and investment facilitation, remove trade barriers, reduce trade and investment costs, increase the speed and raise the quality of regional economic flows and achieve mutually beneficial progress in the region.' Jinping X. (2014). The Governance of China. Beijing, China: Foreign Languages Press Co. Ltd.

2 Speech at the People's Representative Council of Indonesia, 3 October 2013. 'We should work together with our neighbors to speed up connection of infrastructure between China and our neighboring countries, and establish a Silk Economic Belt and a Maritime Silk Road geared towards the demands of the 21st century.' Xi Jinping, 2014. 
performing arts. ${ }^{3}$ Many of the projects are funded by the multilateral development banks, most prominently the Asian Infrastructure Investment Bank and the New Development Bank, at times in partnership with the European Bank for Reconstruction and Development, the European Investment Bank, the Asian Development Bank or the World Bank. Furthermore, the BRI aims to build a network of multilateral and bilateral free trade agreements to support a 'rule-based open trade environment'. ${ }^{4}$

It is difficult to accurately track which are the participating countries in the BRI or the agreements concluded under that label. China seems to adopt a mainly ad hoc partnership-based, relational approach, working with bilateral treaties, agreements and memoranda of understanding - most of which tend not to be publicly available. ${ }^{5}$ It is clear that while a mere ten countries formally joined the initiative after its launch - by signing a Memorandum of Understanding or a cooperation agreement - the project now extends far beyond the initially envisioned corridors, with projects in sub-Saharan Africa, the Pacific, the Caribbean and Latin America. It encompasses an area that reportedly houses 63 percent of the world's population and accounts for 40 percent of the global GDP. ${ }^{6}$ At the time of writing, 18 European member states have reportedly signed BRI-related agree-

3 See for instance the list of bi- and multilateral cooperative agreements and initiatives established at the Second Belt and Road Forum in April 2019 in Beijing. Retrieved from http://en.icdpaso.org/ content/2167.

4 'China's Belt and Road Initiative, Changing the Rules of Globalization', edited by Wenxian Zhang e.a., PSIEM, 2018, p. 77.

5 Wang J. (2019). China's Governance Approach to the Belt and Road Initiative (BRI): Partnership, Relations and Law. Global Trade and Custom's Journal, 14(5), 222-228. At the 2017 inaugural Belt and Road Forum, the Office of the Leading Group for the Promotion of the BRO produced a document called 'Building the Belt and Road: Concept, Practice and China's Contribution.' This document explicates the focus on bilateralism ('preparing bilateral cooperation plans') and refers to the principle of 'achieving shared growth through discussion and collaboration and cooperation' with countries along the Belt and Road. A report by the United States Council on Foreign Relations of March 2021, China's Belt and Road, Implications for the United States, states, e.g.: 'most BRI projects take shape through informal, partnership-based or relational approaches' and '[The BRI] remains remarkably opaque. BRI has no central governing institution. China has not published a master list of BRI projects, the terms of which are often negotiated behind closed doors and kept secret.' (p. vii) 'Opaque lending terms and contracts and closed bidding processes typify BRI projects.' (p. 42) 'Moreover, by engaging in opaque, case-by-case contracting, China makes it difficult for countries to compare notes to understand the relative value of projects or act collectively to push back on unfair terms.' (p. 51).

This report is retrieved from www.cfr.org/report/chinas-belt-and-roadimplications-for-the-united-states/.

6 Sacks D. (2021, March 24). Countries in China's Belt and Road Initiative: Who's in and Who's Out. Council on Foreign Relations. Retrieved from www.cfr.org/blog/countries-chinas-belt-and-road-initiative-whos-andwhos-out. Also see: https://green-bri.org/countries-of-the-belt-androad-initiative-bri/?cookie-state-change $=1623401305741$. The World Bank estimates that for the 70 countries geographically located along BRI transport corridors - excluding China - the investment in all BRI projects would amount to some US\$575 billion. In 2017, these economies accounted for 40 percent of global merchandise exports and received 35 percent of global foreign. It is estimated that the BRI transport projects could ultimately lift 7.6 million people from extreme poverty. Retrieved from www.worldbank.org/en/topic/regional-integration/brief/belt-androad-initiative. ments, and many European companies are participating in BRI projects.

The BRI prompted a wealth of studies, analyses and forecasts, all aimed at pinning down the magnitude and impact of the mega-project, as well as the underlying Chinese intent. This is no easy task because although a quick google search will deliver an impressive list of 'informal' BRI-related organisations and initiatives, there is no overarching, uniform legal regime or governance structure under which the grand strategy is executed.

\section{Dispute Resolution and Mediation for BRI Disputes}

BRI projects are often high-value, multi-party, multi-jurisdictional and always involve state interests. Moreover, the BRI regions and countries differ significantly and fundamentally in terms of their cultural, political and investment environments. Legal traditions vastly differ as do the legal systems' strengths and reliability. These factors not only amplify the chances of a dispute occurring during project realisation but also complicate the dispute resolution process. ${ }^{7}$

Three types of disputes are likely to occur in the context of the BRI: disputes between commercial parties; investor-state disputes; and state-to-state disputes. In this article, I will focus on the first type of disputes: the ones that arise between two 'equal' commercial parties.

In international commercial disputes, litigation in a BRI-host country will not be the most attractive option if the court judgement may need to be recognised and enforced abroad; for instance, in China. As a general rule, China's 'people's courts' tend to recognise and enforce foreign rulings only if this is specifically provided for in a treaty with the country of the judgement's origin - which is rarely the case for BRI countries - or if this follows from the so-called reciprocity principle. This means that a Chinese court will only consider recognising a foreign judgement when courts from the country where that judgement was rendered have previously recognised and enforced a Chinese court judgement. ${ }^{8}$

Arbitration is currently the most popular method to resolve international commercial or investment disputes. This is largely due to the so-called New York Arbitration Convention that ensures almost worldwide easy en-

7 In a Financial Times article of 24 July 2018, consulting firm Arcadis is quoted as stating that about 32 percent of joint construction ventures experience a dispute, and that the average dispute took 14 months to resolve at a cost of $\$ 43 \mathrm{~m}$. The costs are the highest in Asia, with an average of $\$ 84 \mathrm{~m}$ in 2016. Hillman J.E. \& Goodman M.P. China's 'Belt and Road' Court to Challenge Current US-led Order.

8 China did sign the Hague Choice of Court Convention concerning the recognition and enforcement of other member states' court judgments, but, to date, did not ratify that treaty. Dhalan M.R. (2020). Envisioning Foundations for the Law of the Belt and Road Initiative: Rule of Law and Dispute Resolution Challenges. Harvard International Law Journal Essay, 62, 8. Retrieved from https://harvardilj.org/wp-content/uploads/ sites/15/Envisioning-Foundations-For-the-Law-of-the-Belt-and-RoadInitiative-Rule-of-Law-and-Dispute-Resolution-Challenges.pdf. 
forceability of arbitral awards. Of the sixty-five original Belt and Road jurisdictions, only five countries have not ratified the New York Convention. ${ }^{9}$ Stepping up to meet the new BRI demand, a number of Chinese and non-Chinese international arbitration institutions adapted their rules to cover investment disputes, concluded agreements and developed initiatives to cooperate or join forces. ${ }^{10}$ These institutions also frequently offer mediation services, for instance in a hybrid procedure that allows for the settlement agreement reached in mediation to be translated into an (internationally easily enforceable) arbitral award. ${ }^{11}$

\section{China's Preference for Mediation}

However, as mentioned, China actively encourages the use of mediation in BRI dispute resolution. It maintains that consensus-driven methods of dispute resolution better rhyme with the Chinese and Asian cultural norms. These norms and values - some dating back 2.5 millennia to Confucius' teachings - emphasise the importance of avoiding confrontation, protecting harmony and seeking compromise. Openly criticising, showing fury or pursuing personal gain is frowned upon and may result in 'loss of face', which harms one's dignity. This at least partially explains why Chinese parties are often reluctant to initiate litigation, and, instead, prefer to rely on the often-intricate relationship networks ('guanxi') to reach a negotiated outcome as an alternative to imposing the rules of the law. ${ }^{12}$

Mediation has a long history in China. There exists an impressive traditional system of community mediation that became integrated into the legal system. In China's

These are Iraq, the Maldives, Timor-Leste, Turkmenistan and Yemen. Retrieved from www.hkiac.org/Belt-and-Road/new-york-convention-beltand-road-countries.

10 Within Mainland China, the Beijing Arbitration Commission (BAC) entered into an 'institutional coalition' with the Kuala Lumpur Regional Centre for Arbitration (KLRCA) and the Cairo Regional Centre for International Commercial Arbitration (CRCICA). In collaboration with the Nairobi International Arbitration Centre, it established a China-Africa Joint Arbitration Centre (CAJAC). Zhiwei L. (16, October 2017). Belt and Road a Turning Point for Arbitration in China? Retrieved from https://law. asia/belt-road-turning-point-arbitration-china/.

11 For instance, in September 2017, China's International Economic and Trade Arbitration Commission, better known as CIETAC, heralded the adoption of international investment arbitration rules for state-investor disputes, seamlessly fitted to BRI disputes. CIETAC also offers mediation services and the option to have a settlement agreement put down in an arbitral award (retrieved from www.cietac.org); the Hong Kong International Arbitration Center (HKIAC) set up a 'Belt and Road Advisory Committee', and its arbitration rules, revised in 2018, allow for the recording of a settlement agreement in an arbitral award; the Singapore International Arbitration Centre (SIAC) released Investment Rules in January 2017 and works with the Singapore International Mediation Centre in an 'Arb-Med-Arb' scheme.

12 Shining G. (25, June 2018). The Rise of Chinese Investors as Claimants: What Are the Likely Impacts on International Arbitration? Retrieved from www.chinalawinsight.com/2018/06/articles/dispute-resolution/therise-of-chinese-investors-as-claimants-what-are-the-likely-impacts-oninternational-arbitration/. most recent five-year 'Plan on Building Rule of Law in China (2020-2025)', 'people's mediation' is mentioned as the 'first line of defense', and the ambition is to bolster the systems of people's, administrative and judicial mediation. ${ }^{13}$ Independent mediators, who work without supervision or involvement of government institutions or the judiciary, currently play no significant role in the Chinese legal system. However, China is looking to change this as it recognises the growing importance of and demand for international commercial mediation. The Hong Kong Mediation Centre (HKMC) now offers international commercial mediation training courses, with the option of HKMC accreditation, in mainland China. Furthermore, China's oldest and most renowned provider of commercial mediation services, the China Council for the Promotion of International Trade (CCPIT)/ China Chamber of International Commerce Mediation Center (CCPIT Mediation Center), developed a joint international commercial mediation training with the UK-based Centre for Effective Dispute Resolution (CEDR), to be conducted in China. ${ }^{14}$

\section{Chinese Mediation Initiatives in BRI Disputes}

The Chinese commitment to promote mediation takes different forms and shapes. On the ground, in BRI countries, the 'International Commercial Mediation Center for the Belt and Road' (BNRMC) trains mediators and offers mediation services. ${ }^{15}$ The BNRMC is an initiative developed under the patronage of a Beijing-based law firm, but it also opened two satellite mediation offices in Kazakhstan and is recognised by the Chinese government. Between its launch in 2016 and August 2019, the BNRMC purportedly heard 585 cases with a 65 percent settlement rate. ${ }^{16}$

To encourage the parties to (international commercial) BRI conflicts to opt for mediation and arbitration in China, the CCPIT and the China Chamber of International Commerce set up the International Commercial Dispute Prevention and Settlement Organization (ICDPASO) in October 2020. The services of this organisation include commercial mediation, arbitration and investment arbi-

13 The five-year Plan also speaks the need to develop a 'fair and reasonable international rule system' and 'the advancement of the construction of a legal system applicable outside the jurisdiction of our country'. This should be done through multilateral and bilateral dialogue and cooperation with foreign countries, with the instruction to 'tell the story of the rule of law in China'. In this 'story', the central notion is 'the socialist rule of law with Chinese characteristics' under the Chinese Communist Party's centralised and unified leadership. There is no question of separation of powers or an independent judiciary - two preconditions to a Western understanding of rule of law. An unofficial translation of the plan is retrieved from the website: www.chinalawtranslate.com/.

14 Shang C.S. \& Huang Z. (2020). Singapore Convention in light of China's Changing Mediation Scene. Asia Pacific Mediation Journal, 2(1), p. 79-80.

15 Part of the Beijing Retio Legal and Commercial Service Center for the BRI. Retrieved from www.bnrmediation.com/EN/About.

16 https://iclg.com/alb/10172-ibaseoul-beyond-the-belt-and-road. 
tration, as well as dispute prevention. ICDPASO is a Beijing-based non-governmental and non-profit organisation, but - according to its website - it has 50 'members' from 96 countries and regions in Asia, Europe, Africa and South America, including the European Union, Italy, Belgium and Poland. It is reportedly supported by a range of international and multilateral organisations such as the International Chamber of Commerce, the United Nations Commission on International Trade Law (UNCITRAL) and the World Intellectual Property Organisation. ${ }^{17}$

Apart from the information on the organisation's own website - which is still very incomplete and partially 'under construction' - there is still remarkably little mention of the ICDPASO online. The one 'solid' article that seems currently available describes how the ICDPASO aspires to be an international but 'Asia-centric' forum for the settlement of commercial and investment disputes - meaning it will employ dispute resolution techniques that match well with Asian cultures. ${ }^{18}$ The organisation's mediation and arbitration rules, which were reportedly drafted by a group of experts from ten countries and regions, propose mediation as the first (albeit not mandatory) step in resolving any dispute brought before the ICDPASO. In July 2020, these rules were presented to the CCPIT. It is unclear what their current status is.

\section{China International Commercial Courts}

China hopes that high-profile BRI cases involving a Chinese party will be brought to one of the two China International Commercial Courts (CICC), which were launched in June 2018 specifically for this purpose. The First International Commercial Court, in Shenzhen, Guangdong, handles disputes related to the 'Maritime Silk Road', and the Second International Commercial Court, in Xi'an, Shaanxi, is set up for disputes arising from the land-based 'Silk Economic Belt'. ${ }^{19}$

Different from the ICDPASO, the CICC is a genuine Chinese court, created under the auspices of the Chinese Supreme People's Court (SPC). It does, however, claim to operate as a 'one-stop-shop' for international dispute resolution, combining services in litigation, arbitration and mediation. ${ }^{20}$ The CICC is equipped with an international expert committee to advise on the application of foreign laws. These experts cannot - by Chinese law act as judges, but they can be called upon as mediators. Moreover, the CICC is linked with other Chinese (but

17 http://en.icdpaso.org/.

18 Wang G. \& Sharma R. (8, March 2021). The International Commercial Dispute Prevention and Settlement Organization: A Global Laboratory of Dispute Resolution with an Asian Flavor. America Journal of International Law, 115: 22-27, posted on at the SSRN eLibrary.

19 http://cicc.court.gov.cn/html/1/219/208/209/1316.html.

20 Art. 11 of the Provisions of the Supreme People's Court on Several Issues Regarding the Establishment of the International Commercial Court. internationally focused) mediation and arbitration institutions in a dispute resolution 'platform'. ${ }^{21}$ If a settlement agreement is reached in a mediation conducted by the CICC's expert committee or facilitated by one of the institutions recognised in the platform, the court can 'validate' this settlement agreement or issue a judgement on the basis thereof. This can, of course, be particularly useful if the agreement/judgement needs to be executed in China - for instance, if the defendant is a Chinese state-owned enterprise with assets in China.

Although the 'one-stop-shop-idea' may seem appealing at first glance, some of the CICC's practical features will make it difficult to attract a steady flow of cases. Firstly, the CICC's jurisdiction is limited to international civil matters. Investor-state or inter-state disputes are excluded. ${ }^{22}$ Secondly; the CICC accepts cases with a disputed amount of at least RMB 300 million $^{23}$ - a sum of some $€ 40$ million. This is problematic for parties that seek to include an effective dispute resolution clause in their contract - because who can predict whether a potential future dispute will meet this threshold? The CICC may also assume jurisdiction over disputes with a lesser value, upon the referral of a domestic High Court of the SPC, if the case has a 'significant national impact'. It remains to be seen how this standard will be substantiated and applied. ${ }^{24}$ Thirdly, since the CICC is a fully fledged Chinese court, the law dictates that all judges and lawyers appearing before the court must be Chinese nationals, and all proceedings must be conducted in a 'language commonly used in the PRC' - meaning Chinese (or any language of the 55 recognised ethnic minorities in China). Evidence materials may be submitted in English ${ }^{25}$ - but the benefit of this provision is questionable if the materials are subsequently to be used in Chinese language proceedings. And lastly, for non-Chi-

21 The recognised organisations are the China International Economic and Trade Arbitration Commission (CIETAC), the Shanghai International Economic and Trade Arbitration Commission (SHIAC), the Shenzhen Court of International Arbitration (SCIA), the Beijing Arbitration Commission (BAC), the China Maritime Arbitration Commission, the Mediation Center of China Council for the Promotion of International Trade and the Shanghai Commercial Mediation Center. Retrieved from http:// cicc.court.gov.cn/html/1/219/208/210/1144.html.

22 Such cases could be referred for arbitration with one of the institutions in the CICC platform, four of which have recently adopted, or announced to adopt soon, investor-state arbitration rules. As mentioned, CIETAC adopted ruses for investor-state disputes in 2017; SHIAC announced on its website that its rules will soon be updated to include articles on investor-state disputes; SCIA takes on investor-state disputes since 2016 and BAC adopted Investment Arbitration Rules in 2019.

23 Supreme People's Court on Several Issues Regarding the Establishment of the International Commercial Court, Art. 2. This article states that the CICC also accepts cases that were referred by the higher people's courts; cases that have a nationwide significant impact or cases that the SPC considers appropriate to be tried by the CICC. It is, of course, difficult to predict what constitutes 'a nationwide significant impact' or what criteria will be used for the determinations of 'appropriateness'.

24 Chaisse J. \& Qian X. (5, January 2021). Conservative Innovation: The Ambiguities of the China International Commercial Court.AJIL Unbound, 115, 17-21. doi:10.1017/aju.2020.81.

25 Sun W. International Commercial Court in China: Innovations, Misunderstandings and Clarifications. Retrieved from http://arbitrationblog. kluwerarbitration.com/2018/07/04/international-commercial-courtchina-innovations-misunderstandings-clarifications/. 
nese parties interested in mediation, the fact that only Chinese institutions are included in the CICC's dispute resolution platform may be a reason to consider these as not entirely 'neutral'. And there would be sufficient alternatives for the CICC since a number of other non-Chinese international institutions are offering arbitration, mediation or mixed-mode services tailored to BRI disputes.

For this reason, according to international critics, there is little raison d'être for the CICC, other than to protect Chinese interests and to increase Beijing's control. ${ }^{26}$ It is their fear that less powerful parties from BRI countries, that look to enter into a contract with a Chinese stateowned enterprise, will feel compelled to agree to the CICC's jurisdiction. They will then need to hire Chinese lawyers to handle their case in a process that will be governed and decided according to rules that primarily serve Chinese interests. ${ }^{27}$ This view rhymes with claims in Chinese state media that the existing mechanisms for international dispute resolution are 'complicated, time-consuming and costly' and that these 'cannot adequately protect the legitimate interests of Chinese enterprises. Therefore, a fair and transparent dispute settlement regime is necessary'. ${ }^{28}$ It is also interesting to note the claim of the aforementioned CCPIT in a 2018 interview, that Chinese enterprises lost more than 90 percent of the cases brought to international arbitration institutions. ${ }^{29}$

\section{China's Initiatives with Its} Allies

Hong Kong, and in particular China's old friend Singapore, side with China as outspoken advocates for the use of mediation to resolve BRI disputes. A number of collaborative projects were developed for this purpose, which seem to be backed by the Chinese government. The CCPIT Mediation Center and the HKMC launched the 'Mainland-Hong Kong Joint Mediation Centre' for BRI disputes in 2015; ${ }^{30}$ in 2017 and 2019, the CCPIT Me-

26 Mardell J. (14, February 2018). Dispute Settlement on China's Terms: Beijing's New Belt and Road Courts. Retrieved from https://merics.org/ en/analysis/dispute-settlement-chinas-terms-beijings-new-belt-androad-courts.

27 Ang L. International Commercial Courts and the Interplay between Realism and Institutionalism: A Look at China and Singapore, paper presented at 14 November 2019, Harvard International Law Journal. Retrieved from https://harvardilj.org/2020/03/international-commercial-courtsand-the-interplay-between-realism-and-institutionalism-a-look-atchina-and-singapore/; Jacob Mardell, 2018; US Council on Foreign relations, March 2021.

28 Quanlin H. \& Xiaochen C. (1, February 2018). Belt and Road Requires New Global Dispute Regime. Global Times (an English-language tabloid under the Chinese Communist Party's main newspaper, the People's Daily). Retrieved from www.globaltimes.cn/content/1087858.shtml.

29 Cai W. \& Godwin A. (2019, November 3). Challenges and Opportunities for the China International Commercial Court. International \& Comparative Law Quarterly, 68(4), 869-902. Retrieved from SSRN: http://dx.doi. org/10.2139/ssrn.3479860.

30 http://mhjmc.org/en/. diation Center agreed with the Singapore International Mediation Centre to set up a mediation centre for BRI disputes; ${ }^{31}$ in 2017 'e-Bram' was first developed, a Hong Kong-based online dispute resolution and deal-making platform (again the 'one-stop-shop'-format) tailored to disputes relating to BRI infrastructure projects; ${ }^{32}$ and that same year the CCPIT Mediation Center agreed with the Malaysian Mediation Centre to set up a Malaysia-China Business Mediation Center.

In 2019, Mr. Edwin Tong, Singapore's Senior Minister of State for Law and Health, stated:

'Asia is reclaiming its historic weight in the global economy .... From 2000, the world's economic center of gravity has started shifting back to Asia. This heralds the start of a new Asian Century.' ... 'the rules and procedures for settling cross-border commercial disputes today are generally adversarial and embody western values and norms.' ... 'what is common across Asia is the value which Asians place on relationships, preserving harmony' ... 'Asian businesses need an alternative way of settling disputes that prioritise preserving the harmony and ensuring relationships continue, and also not having the situation of one person wins and one person loses, but more commonly known as a win-win situation.'... 'Singapore and China can work together to co-develop a new way of settling cross-border commercial disputes that better reflects Asian values and is also tailored to Asia's needs [; and] to promote mediation as an alternative form of dispute resolution. 33

It is worth noting that the 'mediation first' idea was also taken on by the Court of Arbitration of the International Chamber of Commerce (ICC), which set up a Belt and Road Commission and published 'Guidance Notes on Resolving Belt and Road Disputes using Mediation and Arbitration'. ${ }^{34}$ This documents states:

For Chinese parties, the overriding objective when resolving a dispute is generally to preserve the commercial relationship, on a basis that both sides can accept. In China, agreeing to mediate indicates a de-

31 Reports are available at the SIMC's website. Singapore engaged itself in the BRI, not so much as a recipient country but by investing and developing joint BRI projects with China and other countries (e.g. the so-called Chongqing Connectivity Initiative, an inter-governmental project to improve transport and trade in China's western region); as well as by offering a wide range of services and expertise in the development of BRI projects including dispute resolution services. An estimated 35 percent of outbound BRI investments and 85 percent of inbound financial flows from BRI countries to China pass through Singapore. Fernando M. (2021, 24 February). Singapore's Role in the BRI: Staying Relevant. OBOReurope. Retrieved from www.oboreurope.com/en/singapore-role-bri/.

32 www.ebram.org/. Also, at this summit, a proposal was discussed for a uniform dispute resolution clause for BRI contracts that would require the parties to first try mediation before initiating arbitral proceedings. It is unclear whether a resolution was adopted to that effect.

33 Opening address at the China-Singapore International Commercial Dispute Resolution Conference on 24 January 2019 in Beijing, China. Retrieved from www.mlaw.gov.sg/news/speeches/sms-speech-at-chinasingapore-international-commercial-dispute-resolution-conference.

34 https://iccwbo.org/content/uploads/sites/3/2019/02/icc-guidancenotes-belt-and-road-disputes-pdf.pdf. 
sire to put the relationship back on track.... As Belt and Road disputes typically have at least one Chinese party, we recommend that mediation always be considered for Belt and Road disputes. Ideally, this will happen at the contract drafting stage..$^{35}$

\section{What to Make of China's Support for Mediation?}

Or, what is China talking about when it talks about mediation? The traditional Chinese 'people's mediators', who mostly work at a community level, have a reputation of working in a very determined and at times intrusive manner, not hesitating to pressure parties to compromise - techniques that are very different from the facilitative methods that are commonly taught in the US, Europe and Australia. The people who are 'mediated upon' may not necessarily like this style but choose to participate anyway because it is the socially preferred way of dealing with disputes. ${ }^{36}$

A trace of this 'directive' style of mediating can be recognised in the aforementioned China's International Economic and Trade Arbitration Commission (CIETAC) arbitration rules and in the Hong Kong Arbitration Ordinance. These rules each provide for a hybrid process in which the arbitral tribunal may 'conciliate' (mediate) a dispute during the arbitral proceedings with the consent of both parties. In this procedure, the arbitral tribunal simply switches hats and assumes the role of conciliator - and switches them back to decide the case if the conciliation is unsuccessful. ${ }^{37}$ Given the deliberate amalgamation of the concept of conciliation and mediation in the UNCITRAL Convention on Mediation, one could question whether this process qualifies as mediation in the 'Western' understanding - which is characterised by party autonomy, a voluntary process and a mediator who does not decide the case.

One could also question whether China's preference for mediation is simply a way to avoid closer judicial scrutiny or to exert undue pressure under the veil of confidentiality. In the international context, China presumably has a significant political interest in dealing with BRI disputes in a covert manner. The BRI has an increasingly unfavourable reputation as President Xi's grand scheme to expand Chinese dominance. ${ }^{38}$ Protracted BRI disputes in the public eye would undoubtedly not do that image any good. This might be a reason for China to resolve

35 https://uncitral.un.org/en/texts/mediation/conventions/international_ settlement_agreements.

36 See e.g. Barnes B.E. (2007). Culture, Conflict and Mediation in the Asian Pacific. Lanham: University Press of America, Chapter 5; Stobbe S.P. (2018). Conflict Resolution in China. Lanham: Lexington Books, Chapter 8 on China by Eko Yi Liao and Cheryl Qianru Zhang.

37 Art. 33 of the Hong Kong Ordinance. Retrieved from www.elegislation. gov.hk/hk/cap609?xpid=ID_1438403521102_002.

38 See, for instance, www.businessinsider.com/china-spends-twice-us-butbelt-road-initiative-losing-steam-2021-9? international=true\& $r=U S \& I R=T$. disputes in mediation or at the negotiating table - out of the public eye - while upholding the appearance of legitimacy and respecting contractual freedom.

Of course, mediation (or negotiation) is in essence a voluntary process. If parties feel that the process is not up to par or does not serve their interests, they should, in principle, feel free to switch to arbitration or litigation. In principle, because one can imagine that the parties may feel pressured to accept an outcome that perhaps more directly serves the Chinese party's rather than their own best interest if the contracted alternative route is litigation at the CICC - for all the reasons listed above.

\section{The Significance of the Singapore Convention on Mediation}

In his 2019 speech, quoted above, Singapore's Minister Tong stated that both China and Singapore see the UNCITRAL Convention on International Settlement Agreements resulting from Mediation - also known as 'the Singapore Convention on Mediation' - as important to the multilateral rules-based order. The treaty aims to facilitate the execution of settlement agreements reached in international commercial mediation. ${ }^{39}$ Proponents hope that the instrument will be widely signed and ratified so that the easy enforcement of international mediated settlement agreements across borders will be globally secured - similar to the workings of the socalled New York Convention for international arbitral awards. ${ }^{40}$ The idea is if cross-border recognition and enforcement of mediated settlement agreements is no longer an issue of concern, this will make it easier for international corporations to consider mediation as a serious, and in appropriate cases more attractive, alternative to arbitration.

The idea for the Singapore Convention was first proposed by America, and the treaty was developed by UNCITRAL Working Group II..11 In August 2019, it was signed by 46 countries, and it entered into force on 12 September 2020 for the first six that also ratified the instrument. The EU took part in the preparatory debates and negotiations but has yet to sign the treaty. ${ }^{42}$ At the

39 The United Nations Convention on International Settlement Agreements Resulting from Mediation. Retrieved from https://uncitral.un.org/ sites/uncitral.un.org/files/singapore_convention_eng.pdf.

40 The 1958 Convention on the Recognition and Enforcement of Foreign Arbitral Awards.

41 UNCITRAL is the United Nations Commission on International Trade Law. Working Group II (WGII) focusses on Arbitration and Conciliation / Dispute Settlement. All of UNCITRAL's sixty member states are represented in WGII, and about one-fifth of these countries is European.

42 Although the EU has shown very limited interest in the Convention, I believe there is little to lose and much more to be gained by signing on. Furthermore, Europe's support for the instrument would send a signal that mediation is a full-fledged and legally sound method to solve international commercial disputes. That message would fit well with Europe's 
time of writing, 55 countries signed the Convention. Australia, the latest addition to the list, joined in September 2021. The Convention is ratified by and in force in eight countries. ${ }^{43}$

The vast majority of the signatory countries also participate in the BRI or have recently entered into a bilateral (trade) agreement with China. Actually, only a handful of those countries are not, to some extent, engaged in the BRI. ${ }^{44}$ Seven of the eight countries for which the Singapore Convention entered into force - Turkey, Belarus, Ecuador, Fiji, Qatar, Saudi Arabia and Singapore - are deeply involved in the BRI. ${ }^{45}$ The eighth is Honduras, which deposited the instrument of ratification at the UN headquarters in New York on 6 September 2021. The Convention will enter into force for Honduras on 2 March 2022. Honduras does not take part in the BRI. It recognised and signed a free trade agreement with Taiwan, which constitutes a diplomatic stumbling block for China.

China signed, but did not ratify, the Convention yet and is apparently still a long way from doing so. The fact that China lacks comprehensive domestic rules and procedures for the enforcement of settlement agreements is a practical obstacle, but it is also concerned about the protection of third parties' or public interests, and it worries that the Convention might be misused. And even if those concerns are soon to be assuaged, it will still require a lengthy procedure before the treaty can enter into force. ${ }^{46}$

ambition to help increase the use of mediation in international commercial disputes in the EU, as expressed in the 2008 EU Mediation Directive (2008/52/EC) and the EU Parliament's recommendations in 2017 to address some of the Directive's difficulties. Brink H. (March 2021). The Singapore Convention on Mediation - Where's Europe? Retrieved from Mediate.com; and Hoe moet het verder met het Verdrag van Singapore?, NJB 2021/497.

43 An up-to-date overview is retrieved from https://treaties.un.org/Pages/ ViewDetails.aspx?src=TREATY\&mtdsg_no $=$ XXII-4\&chapter $=22 \&$ clang=_en.

44 Among those are Australia, the United States and India (each outspoken about their distrust of China's intentions), and Eswatini (Swaziland) and Palau (each of which recognised Taiwan). Under the pandemic, China increased its influence in a number of signatory countries like Jordan, Guinea-Bissau and Colombia by generously providing face masks and protective gear, medical equipment, test kits and vaccines.

45 Turkey is a central station in the 'Silk Road Economic Belt'; China and Belarus boast a 28-year-old 'comprehensive strategic partnership' and Belarus committed to promoting the BRI in the Eurasian Economic Union; Ecuador is reportedly the third largest recipient of Chinese finance in the Latin American region, just behind Venezuela and Brazil; Fiji joined the Maritime Silk Road Port Cooperation Plan; Saudi Arabia was one of the first countries to join the BRI and is described as the BRI's 'linchpin' in the Middle East; Qatar is a key financial partner to China in the BRI; and Singapore - one of the most active countries in the development of the Singapore Convention - historically fosters warm relations with China, is described as 'the second-largest off shore renminbi (RMB) trading hub', and it invested in a number of major BRI projects in China's mainland.

Dr. Liu Xiaochun, President of the Shenzhen Court of International Arbitration, in a panel discussion during the 2021 Singapore Convention Week. A video of the discussion can be found online. Dr. Xiaochun also explained that the Convention would first need to be ratified by the $\mathrm{Na}$ tional People's Congress, then issued by the President, and it would subsequently only enter into force for China after six months have passed since deposition of the instrument of ratification with the UNCITRAL secretariat.
China may, however, confidently expect to profit from the Singapore Convention entering into effect in BRI countries, given its pro-mediation approach to BRI dispute settlement. It is safe to assume that this approach is an indication of China's belief that it will manage to secure its interests at the negotiation table. In such cases, it works in China's favour if settlement agreements can easily be executed in BRI countries, should this be required.

\section{To Conclude}

The practical value of the Singapore Convention will be tried and tested if a significant share of the signatory countries eventually ratifies the Convention, and the use of mediation in the context of the BRI indeed takes sustained flight.

Whether mediation, in the context of a BRI dispute, best serves all parties' interests will depend on the particular circumstances of the case at hand and on the integrity of the mediation process. However, the presentation of mediation as the preferred or at least a fully fledged option for BRI dispute resolution, on a par with arbitration and litigation, is in itself commendable.

It will be interesting to see whether, and how, the new and innovative 'mixed-mode' and 'one-stop-shop' BRI dispute resolution mechanisms will develop, and in particular: whether these indeed will deliver fair outcomes and gain international credibility, trust and standing. The BRI can be seen as a field lab for international commercial dispute resolution where values of legitimacy are fully explored: an experiment to surely monitor with great interest in the years and decades to come. 